\title{
Diversification of teaching cognitive styles in higher school as a factor of enhancing the quality of teaching accounting the best European practices
}

\author{
Alexandra Kats $^{1}$ \\ ${ }^{1}$ Institute of Pedagogy, Psychology and Social Problems, Isaeva Str., 12, 420039 Kazan, Russia.
}

\begin{abstract}
In the modern conditions, one of the teacher's leading tasks is achievement of high quality of teaching based on the analysis and accounting of the best European practices, which can be actualized in the context of a research on teaching cognitive styles. The relevance of a research is as follows: teaching cognitive style causes features of an individual style of teacher's professional activity. The purpose of the article is in determination of inter-relation between the research on teachers' cognitive styles and realization of practical aspects of teaching accounting the best European practices. It is formulated that the research of teaching cognitive styles is one of the priority directions of the research which is caused by the need for enhancing the quality of teaching in higher school within achievement of high level of pedagogical mastery. It is proved that inter-disciplinary study of Russian and foreign researchers is aimed to establish individual differences in the ways of teacher's work with information, to model variable situations of pedagogical interaction accounting diversification in models of teachers' intellectual behavior in higher school. The article is intended for the researchers, and teacherspractitioners.
\end{abstract}

\section{Introduction}

In the modern conditions, the emphasis in the course of enhancing teaching practice in higher school is placed on enhancing the quality of teaching that is motivated by the following factors: need of achievement the level of quality teaching coherent to the international quality standards; need to implement adoptive experience of the best European practices in the teachers' professional activity; presence of system of the universities' international ratings (TOP-100) for assessment the quality of teaching; high requirements to the specialists at the educational labour market. The high quality of teaching is based on achievement of high level of pedagogical mastery on the basis of the analysis and accounting of the best European practices, in the course of formation significant pedagogical values, enlargement the role and functions of a modern higher school teacher

\footnotetext{
${ }^{1}$ Corresponding author: cats.schura@yandex.ru
} 
in the educational process (transfer from the mentor to the tutor, the facilitator and a mediator of pedagogical interaction), and greater individualization of teaching process that will promote diversification of approaches to the students' teaching. According to scientific belief of T. Tregubova, L. Shibankova, A. Kats, the quality of education, the efficiency of its development and resultativity are defined by the activity of teaching staff: those people should teach, who make a contribution to science and can form models of students' cognition [1].

Universities' participation in the international, educational projects considerably enriches the practice of teaching, stimulates teachers for the professional growth and development, and is also focused on search of innovative approaches to teaching, innovative forms, methods and technologies of teaching. Active participation of the teacher in international cooperation is one of the most effective instruments for enhancing pedagogical mastery. Participation in the international project activities serves as an "external" motivator for teachers' professional development while the research on teaching cognitive styles in higher school is an "internal" motivator for self-cognition and selfdevelopment. In our opinion, the teacher studying the features of his (her) cognitive sphere is more focused on systemic, internal work, and consciously approaches to the selfreflection of his(her) professional activity.

The research on teaching cognitive styles is one of the priority directions of a research the scientific interest to which is caused by the need for enhancing the quality of teaching in higher school, aspiration to achievement pedagogical mastery on the basis of the analysis and accounting the best European practices, reveal teachers' creative potential in the course of teaching activity. The organization of educational process in higher school becomes more constructive if the teacher doesn't not only possess knowledge of cognitive styles' features, but skillfully implements them into practice and also uses the adoptive, educational potential of the best, European practices in his (her) professional activity. It was found out, that the teachers' (intellectual) behavior in the process of studies is caused by features of the leading, cognitive style. According to scientific opinion of C.Evans C., M.J.Harkins, J.Young, "teachers, who are aware of their preferred teaching style could be encouraged to reflect their teaching behaviours and to develop a range of teaching styles to best meet different learning styles of the learners" [2], which assumes the analysis and accounting of cognitive styles in teachers' professional activity, search of compliance in teacher-student cognitive style. In modern conditions there can be observed a tendency that the range of students' inquiries is enlarged which is caused by emergence of new educational opportunities for students, change of motivation to learning and also high requirements to training of the qualified, competitive specialists in an educational labor market.

According to scientific belief of prof. Tregubova T. M., L.A. Shibankova, A.S. Kats, "Based on the analysis of teachers' cognitive styles, teachers are able to choose, substantiate and improve their tools of teaching" which influence on flexible change and enhancing the didactic organization of studies in the higher school [3]. A young teacher, being in process of his (her) professional establishment, studies his (her) cognitive style to create an individual style of teacher's professional activity. An experienced teacher whose individual style of professional activity has already been created, searches to modify the cognitive style to satisfy students' educational inquiries. Reconsideration and conscious selection of forms, methods and technologies of teaching, relevant to teacher's and students' cognitive style is a result of this internal work of the teacher.

In accordance with scientific positions of M. Darra, enhancing quality of teaching in higher school in the context of research of teaching cognitive styles is based on the following principles [4]: 
1. The process of training students is based on cognitive data processing, respectively, the learning outcomes can be viewed in accordance with teachers' knowledge, skills, attitudes, values formation and their (intellectual) behavior influenced by cognitive abilities of the teacher and the students.

2. Transfer from one level of cognition to another is carried out in case that teachers are able to provide students with different cognitive abilities, an opportunity to study on the basis of differentiated stimuli resources, types of activities and innovative approaches to teaching which will allow them to estimate the learning outcomes more objectively and to model process of teaching on the basis of knowledge generation about features of functioning students' cognition.

3. Application of inter-disciplinary approach to teaching is realized on the basis of the cognitive-centered teaching and suggests competitive advantages both to the teachers and the students. In this context, the teacher becomes a mediator of independent study where students can reveal their cognitive abilities, and the teachers grounding their activity on the cognitive-centered teaching carry out their professional activities more effectively.

\section{Methods of identification teaching cognitive styles and their types}

In the process of our research the following methods were used: the method of psychological and pedagogical experiment, the method of diagnostics on the basis of monitoring; the method of questionnaire; the method of short interviews.

The method of psychological and pedagogical experiment suggests an opportunity to modelling situations on the organization of teachers' professional activity, which are aimed at stimulating the manifestation of personal and professional characteristics, influencing on the style of teacher's professional activity.

The method of diagnostics based on the monitoring is in the ability to study the realization of teachers' professional activity in higher school and on the basis of monitoring to determine the individual differences in the teachers' intellectual behaviour.

The method of questionnaire allowed us to get the relevant data about the formadeness of teaching cognitive style in higher school. It was based on adoptive "Test on reflection. Methodic on diagnostics the level of reflection development" (A.V. Karpov) [5] (cognitive style The Reflection - The Impulsivity) and Test on "Determination the type of orientation - vector of pedagogical activity" (motivation component of the style Cognitive complexity - Cognitive simplicity) (K.M. Levitan) [6]

The method of short interview allowed us to check the relevant data about personal and professional characteristics influencing the style of their professional activity.

The specific feature of the realization the pilot research on teachers' cognitive styles was to prove the degree of validity of the methodic of identification teaching cognitive styles on the basis of methods of expert evaluation of the research results and crossreference of the research results. According to the experts' opinion and results of crossreference, it was found out that the questions of the adoptive methodic reflect the content and motivational aspects of teacher's professional activity.

In modern Russian, scientific literature there contains about 15 types of cognitive styles (apart from isolated cognitive styles). Our research is based on the relevant data provided in a manual "Cognitive pedagogy" according to which there are 9 types of the cognitive styles based on the dichotomized approach (Cognitive pedagogy, 2020)[7]: The Field independence - The Field dependence, The Definiteness - The Abstractness, The Smoothing - The Sharpening, The Rigid informative control - The Flexible informative control, The Low level of tolerance to unreal experience - The High level of tolerance to unreal experience, The Focusing control- The Scanning Control, The Impulsiveness - The 
Reflexivity, The Narrow range of equivalence - The Wide range of equivalence, The Cognitive simplicity - The Cognitive complexity.

R.J. Riding, A. Duglas [8] determined 19 cognitive styles in foreign literature, which have been identified in the modern conditions and are based on the dichotomized approach. Let us outline the most significant of them: The Reflective- The Impulsive Style, The Convergent - The Divergent Construct, The Holist- The Serialist theory, The FieldDependence- The Field Independence Model, The Adoption - The Innovation Theory, The Wholist-The Analytic and The Verbal- The Imaginary Model.

Diversification of teachers' cognitive styles influence on presence of variable, personal and professional characteristics at each teacher that assumes the presence of these characteristics in professional activity of the teacher and forms unique style of teacher's professional activity.

The hypothesis of our research is as follows: it is possible to trace the inter-relation between a research on diversification of teachers' cognitive styles in higher school and enhancing the quality of teaching in higher school, relying on studying teacher's personal and professional characteristics affecting character and vector of his (her) professional activity.

\section{Analysis of sources on teachers' cognitive styles}

Applying to the best European practices on research of teachers' cognitive styles, we have studied the works of foreign researchers on influence of teaching cognitive styles on quality of teaching in higher school (M. Grimley, G. Banner; L. Zhang; C.L. Samms) [9; 10;11] and studying influence of cognitive styles of students on quality of teaching at the higher school (S. Atkinson; C. Peklaj; A. Gellel)[12,13,14]. Modern, foreign researchers share the common opinion that the research on cognitive styles allows them to establish inter-relation between teachers' cognitive style and the degree of efficiency of teacherstudent work, measured in learning outcomes. M. Grimley, G. Banner [9] found out that there is a correlation between working memory, teachers' cognitive styles, and teachers' (intellectual) behavior in the process of studies and students' performance during the certified, final examination (measured in learning outcomes). It was revealed, that the best performance was achieved by "analytic verbalisers". L. Zhang [10] was the founder of the scientific theory allowing an opportunity to predict the learning outcomes and enhance teaching practice in higher school by means of the research on teaching cognitive styles. $\mathrm{He}$ investigated the predictive power on teacher-student cognitive style match-mismatch performance on 3 academic disciplines: Mathematics, Physics, and Public administration. It was found out that in the course of studying discipline "Public administration" the correlation between teacher-students' cognitive styles was the highest, the lowest correlation was traced when studying discipline "Physics". C.L. Samms [11] suggested that by means of drawing up the cognitive map for the teachers and the students it was found out that the teacher is capable to use his(her) abilities of the cognitive style more efficiently, than the student does (accounting age, cognitive, individual, and personal differences). The significant contribution to the research of students' cognitive styles was made by S. Atkinson [12]. He investigated students' cognitive abilities, and came to a conclusion that a kinesthetic and a verbal type of a person possess the highest resultativity, while the visual learners have the lowest results in teaching.

In the process of our experimental work, we conducted a pilot research on identification of teachers' cognitive styles in higher school on the basis of FSBSI "Institute of Pedagogy, Psychology and Social Problems" and the Kazan (Volga -region) Federal University. In the process of identification teaching cognitive styles in higher school there participated 54 respondents and 3 internal experts who possess a sufficient pedagogical experience and the 
formed individual style of pedagogical activity. The relevance of the conducted pilot research is caused by the fact that process of knowledge transfer, formation of competences and the organization of multi-dimensional pedagogical communications between the subjects of education with different types of thinking and perception is essentially important.

In this respect, there was a need for identification the leading teachers' cognitive styles"The Reflexivity-The Impulsiveness", "The cognitive complexity - The cognitive simplicity", affecting features of teacher's professional activity. The specific feature for the realization of a pilot research on teachers' cognitive styles was that during the pilot research the degree of validity of tests on identification teaching cognitive styles on the basis of expert assessment of the results of a research and cross-reference of the results of a research was defined.

On the basis of conducted research we have come to the following results of a research:

1. Growth of interest to the problem of identification teaching cognitive styles by the participants of research was motivated by the desire of teachers to obtain high level of pedagogical mastery. The teachers showed their motivational readiness to participate in a pilot research, openness to discuss key aspects of pedagogical activity and also an objective and fair self- reflection of pedagogical activity that allowed to receive the most reliable results of a research.

2. Results of questionnaire were carefully re-checked by method of an expert assessment. According to the results of expert assessment, the conducted pilot research is rather valid as questions of the test were prepared taking into account determination of the objective criteria of pedagogical activity, they are logically -interconnected and directly formulated.

3. Results of questioning were checked also by method of cross-reference the results of research allowing us to receive "feedback" from the respondents who were taking part in pilot questionnaire. Most of the respondents confirmed that the obtained data was comparable to their professional position, professional preferences, motivational readiness for implementation of professional activity, and a desire to enhance teaching practice.

Applying to these data, we developed the questionnaire for "feedback" with "cognitivecentered" the teacher which reveals the inter-relation of research on teaching cognitive styles with practical aspects of teaching (Table 1)

Table 1. Inter-relation of research on teaching cognitive styles with practical aspects of teaching.

\begin{tabular}{|l|l|l|l|}
\hline No & Aspects of teaching & $\begin{array}{l}\text { Key questions for teachers' } \\
\text { overestimation on teaching } \\
\text { cognitive styles }\end{array}$ & $\begin{array}{l}\text { Conclusions on the aspects of } \\
\text { teaching (accounting the influence } \\
\text { of cognitive style) }\end{array}$ \\
\hline 1 & Volume of material & $\begin{array}{l}\text { How can } \\
\text { I structure the material for } \\
\text { teaching in th most } \\
\text { appropriate way? }\end{array}$ & $\begin{array}{l}\text { Structuring the information/ } \\
\text { material is made in accordance with } \\
\text { specific features and personal- } \\
\text { professional characteristics of } \\
\text { students }\end{array}$ \\
\hline 2 & $\begin{array}{l}\text { Ways of presenting } \\
\text { material }\end{array}$ & $\begin{array}{l}\text { What is the most appropriate } \\
\text { way of working with } \\
\text { information, that will lead to } \\
\text { successful fulfillment of the } \\
\text { task? }\end{array}$ & $\begin{array}{l}\text { The work with information should } \\
\text { be realized in a system: } \\
\text { comprehension of information, } \\
\text { processing information, structuring } \\
\text { the information, systematization of } \\
\text { information, generation of } \\
\text { knowledge, translation of } \\
\text { knowledge }\end{array}$ \\
\hline 3 & Speed, pace and & What is the influence of the & The pace of presenting information \\
\hline
\end{tabular}




\begin{tabular}{|c|c|c|c|}
\hline . & changes of activities & $\begin{array}{l}\text { pace of teaching on completion } \\
\text { different kinds of activities? }\end{array}$ & $\begin{array}{l}\text { depends on personality's cognitive } \\
\text { abilities and functioning of his (her) } \\
\text { cognition }\end{array}$ \\
\hline 4 & $\begin{array}{l}\text { Modeling of match } \\
\text { between creative } \\
\text { and rational way of } \\
\text { thinking }\end{array}$ & $\begin{array}{l}\text { Am I struggling to stimulate } \\
\text { students' } \\
\text { development? }\end{array}$ & $\begin{array}{l}\text { Correlation between cognitive style } \\
\text { and creative way of thinking was } \\
\text { established. The research on } \\
\text { cognitive style is based on rational } \\
\text { way of thinking }\end{array}$ \\
\hline 5 & $\begin{array}{l}\text { Diversification of } \\
\text { cognitive styles in } \\
\text { the aspect of } \\
\text { teacher's } \\
\text { professional activity }\end{array}$ & $\begin{array}{l}\text { Am I using the whole range of } \\
\text { cognitive styles in my } \\
\text { professional activity? }\end{array}$ & $\begin{array}{l}\text { Each teacher has } 1 \text { dominating } \\
\text { cognitive style, other styles are } \\
\text { considered valuable (they comprise } \\
\text { the range of teaching cognitive } \\
\text { styles) }\end{array}$ \\
\hline 6 & $\begin{array}{l}\text { Self-study } \\
\text { guided study }\end{array}$ & $\begin{array}{l}\text { Am I developing the students' } \\
\text { ability to self-study and guided } \\
\text { study? }\end{array}$ & $\begin{array}{l}\text { Research on teachers' cognitive } \\
\text { styles assumes an ability of the } \\
\text { teacher to self-reflection. Such type } \\
\text { of a teacher is motivated on } \\
\text { development students' abilities to } \\
\text { self-study }\end{array}$ \\
\hline 7 & $\begin{array}{l}\text { Structure } \\
\text { organization } \\
\text { studies }\end{array}$ & $\begin{array}{l}\text { Am I using the structure of the } \\
\text { lesson to provide the learning } \\
\text { outcomes? }\end{array}$ & $\begin{array}{l}\text { Research on cognitive styles } \\
\text { assumes the ability of structuring } \\
\text { and systemizing the information, } \\
\text { that allows the teacher to organize } \\
\text { efficiently the educational process } \\
\text { in higher school }\end{array}$ \\
\hline 8 & Evaluation & $\begin{array}{l}\text { Am I using the abilities of } \\
\text { students' complex assessment } \\
\text { in accordance with the tasks of } \\
\text { teaching? }\end{array}$ & $\begin{array}{l}\text { Study on teachers' cognitive styles } \\
\text { serves to help the teacher to } \\
\text { estimate his cognitive abilities and } \\
\text { give an objective evaluation of } \\
\text { students' cognitive potential }\end{array}$ \\
\hline
\end{tabular}

Subsequently, the teachers researching cognitive styles have a range of the personal and professional characteristics which are positively influencing enhancing the quality of teaching:

1. The cognitive-centered teacher is able to structure the information that allows him (her) to organize efficiently the logical structure of studies in higher school, and to approach flexibly the organization of educational process in higher school.

2. The cognitive-centered teacher is determined to introspection and self-reflection that will provide critical reconsideration of key positions in teaching. The self-reflection he implements is designed to help the teacher to enhance the practice of teaching in higher school that is achieved by the deliberate choice of relevant forms, methods and technologies of teaching and leads to the change of teaching didactics.

3. The cognitive-centered teacher is more objective in the subjective assessment, provides logical arguments for subjective assessment. The logicality of reasoning is a distinctive feature of the cognitive-centered teacher.

Admitting presence of diversification of teaching cognitive styles in higher school affecting the style of their professional activity we have come to the following conclusions:

1. Each teacher has the unique personal and professional characteristics shaping his (her) individual, cognitive style depending on features of work with information.

2. Implementations of the range of teaching cognitive styles applied by the teacher in the course of teaching is aimed to enrich the teaching practice by means of diversification 
of approaches to teaching and also the deliberate choice of means of teaching, relevant to teacher's and students' cognitive style can be traced.

3. The efficiency of teaching, is oftentimes caused by the conscious approach towards research of the range of teaching cognitive styles in higher school,teacher's ability to carry out self-reflection of professional activity on the basis of self-cognition in the course of teacher's cognitive organization.

Thus, in modern conditions the emphasis is placed on formation of the innovative teacher who has formed professional values, theoretical knowledge, practical skills, who performs professional activity taking into account the best European practices that allows him (her) to reach the high level of pedagogical mastery and to achieve the best learning outcomes.

\section{Conclusions}

Let us outline the most significant results, we have come to in the process of our research of teaching cognitive as a factor of enhancing the quality of teaching:

1. The research on teaching cognitive styles allows us to reach the maximum quality of teaching, based on cognitive abilities of the teacher and the students. The teacher inclined to self- reflection of pedagogical activity and introspection of cognitive styles can approach more flexibly the modeling of situations of pedagogical interaction. In the course of teaching based on the research of teaching cognitive styles greater individualization of teaching and more humanistic-centered focus of teaching will be observed.

2. Influence of cognitive styles on the differentiated ways of work with information will be especially significant for achievement the quality of teaching. Based on the research of teacher's cognitive processes, it is possible to predict teacher's intellectual behavior in the process of studies in higher school that will allow the teacher to focus on definite aspects of teaching.

3. Studying the features of teachers' cognitive styles allows the teacher to enhance teaching didactics as the analysis and accounting of cognitive styles allows to provide the differentiated approach to deliberate choice of relevant forms, methods and technologies of teaching.

The mismatch of teacher's and students' cognitive styles significantly affects the learning outcomes and students' motivation to learning. Respectively, an appeal of researchers and practicing teachers to the problem of research on teaching cognitive styles is based on the fact that the efficiency of teaching activity is based on accounting of students' personal and professional characteristics and their educational preferences.

To sum up, cross-disciplinary research in the field of cognitive styles confirmed our hypothesis of correlation between teaching cognitive style with enhancing the quality of teaching. We support the scientific opinion of O. O. Olagbaju [15], the cognitive style of the teacher is "a teacher's consistent way of responding to, interpreting and using stimulti in the context of learning". Therefore, the research of cognitive style is not really concerned on what the student studies (content of learning), but it is about the ways and strategies which the student uses in the course of work with information (cognitive ways and cognitive strategies of data processing). The cross-disciplinary research is aimed to suggest researchers an opportunity to establish individual differences in the ways of work with information, to model variable situations of pedagogical interaction taking into account diversification of models of intellectual behavior of teachers of the higher school. According to scientific opinion of Z. A. Bakar, A. Rafaquat [16], the research on cognitive styles can be applied to enhancing teaching practice in higher school, and will allow to achieve the best learning outcomes in different types of activities. As a result of researches of foreign scientists-researchers (C. Evans; M.Warning; S. Hubackova; N. H. Wulandari, 
K.A. Widayati, B.Suryobroto; L.Sellah; K. Jacinta,H.Mondoh) $[17,18,19,20]$, it was found out that it is necessary to match teacher-student cognitive style on $75 \%$ for enhancing the quality of teaching and nearly $32 \%$ of respondents meet this requirement; $31 \%$ of respondents match teacher-student cognitive styles on 50\%, and demonstrate rather good match between the teacher and students. The teacher-student match on less, than $25 \%$, can lead to the conflict of styles, and will significantly reduce the quality of teaching.

According to scientific opinion of C.Evans [21], the research on teaching cognitive styles of teachers influences on a preparatory phase for the training students which includes the following aspects: the preparation and organization of the content of teaching, deliberate choice of educational resources, the conscious choice of the tasks directed to reveal students' cognitive abilities, and also planning "feedback" with the students. Applying to the course of training students, cognitive styles influence on the didactic organization of studies: structuring the studies, speed and pace of information presentation, organization of pedagogical interaction, flexibility of the studies organization, fair, teacher's subjective assessment. Respectively, the cognitive-centered teacher in the process of studies in higher school, searches to consider the teacher-student match of cognitive styles in correlation with other phenomena that allows him(her) to provide enhancing of teaching practice in higher school. Conscious approach to recognition of diversification of teaching cognitive styles allows us to identify and consider differences in individual (intellectual) behavior of the teacher in the process of studies. We believe that enhancing of teaching practice in higher school can be realized via means of improvement the quality of teaching that assumes change of the didactic organization of studies on the basis of research on teachers' cognitive styles in higher school, and accounting the cognitive features of the personality in the process of studies.

\section{Acknowledgements:}

The research in ENTEP-project was funded by Education, Audio-visual and Culture Executive Agency, Erasmus+, ref.: 586225-EPP-1-2017-1-DE-EPPKA2-CBHE-JPENTEP. The authors are also grateful to all partners of ENTEP team with their valuable contributions to discussions and verification of the developed procedures.

\section{References:}

1. T.Tregubova, A. Kats, L.Shibankova Materials of VI International Forum on pedagogical education "Perspectives and priorities of pedagogical education in the era of transformations, choice and challenges", 309 (2020)

2. C. Evans, M.J. Harkins, D. J. North Am. J. of Psych., 10, 567 (2008)

3. T. Tregubova, L. Shibankova, A. Kats Arpha Proc., 2595 (2020)

4. M. Darra. Int. J. of Ec.\& Business Adm., 1, 4, 137 (2013)

5. A. Karpov Psych. J., 24, 5, 45 (2003)

6. K. Levitan Foundations of pedagogical deontology (1994)

7. R. Gilmeeva, A. Kamaleeva, A. Kats, E. Levina, V. Maslennikova, L. Mukhametzyanova, T. Tregubova, L. Shibankova Cognitive pedagogy (2020)

8. R.J. Riding, G. Douglas British J. of Educational Psychology, 63(2), 297 (1993)

9. M. Grimley, G. Banner Int. J. of Exp. Ed. Psych., 28(3), 341 (2008)

10. L. Zhang Int. J. of Exp. Ed. Psych., 26(3), 395 (2007)

11. L. Samms Relationship between dissimilar cognitive styles, use of coping behaviour, and use of learning strategies. (A dissertation submitted in fulfillment of requirements for the degree of Doctor of Philosophy for Louisiana State University) (2010) 
12. S.Atkinson Int. J. of Exp. Ed. Psych., 24(5), 659 (2010)

13. C. Pekai Hor. of Psych., 12(4), 9 (2003)

14. A. Gellel Materials of 11-th biennal conference of the European Association for Research on Learning and Instruction (2005)

15. O.O. Olagbaju Ed. Res. Int., 1 (2020)

16. Z. A. Bakar, A. Rafaquat. Materials of 2-nd International Seminar on Quality and Affordable Education. ISQA E2013, 536 (2013)

17. C. Evans, M. Warning Ed. Research for Policy and Practice, 10(3), 149 (2011)

18. S. Hubackova Proc.- Soc. and Beh. Sciences, 197, 1952 (2015)

19. N. H. Wulandari, K.A. Widayati, B. Hayati J. of Biosc., 23, 121 (2016)

20. L.Sellah, K.Jacinta, H. Mondoh Cog. Psych., 5, 1 (2018)

21. C. Evans Int. J. of Exp. Ed. Psych., 24(4), 509 (2010) 